\title{
Cost-benefit analysis of different fattening systems with Tuj and Hemşin lambs in controlled conditions
}

\author{
Erol AYDIN ${ }^{1}$, Mehmet SARI $^{2}$, Kadir ÖNK ${ }^{3}$, Yüksel AKSOY ${ }^{4}$, Yılmaz ARAL $^{5}$ \\ ${ }^{1}$ Kafkas University, Faculty of Veterinary Medicine, Department of Livestock Economics and Management, Kars; ${ }^{2}$ Mehmet Akif \\ Ersoy University, Faculty of Veterinary Medicine, Department of Animal Science, Burdur; ${ }^{3}$ Kafkas University, Faculty of Veterinary \\ Medicine, Department of Animal Science, Kars; ${ }^{4}$ Eskişehir Osmangazi University, Faculty of Agriculture, Department of \\ Zootechnics, Department of Animal Breeding, Tokat; ${ }^{5}$ Ankara University, Faculty of Veterinary Medicine, Department of Animal \\ Health Economics and Management, Ankara, Turkey.
}

Summary: This study aims to determine the most profitable fattening system through an economic analysis of lamb fattening in different fattening systems under controlled conditions which was performed for the first time in Turkey. The material of the study consists of 39 weaned lambs of 2.5-3 months old from each of the Tuj and Hemşin genotypes. In the study, the lambs were separated into the 3 fattening groups of extensive, semi-intensive and intensive including 13 Tuj and 13 Hemşin lambs in each group through the systematic sampling method in a diagonal manner and these lambs were subject to 90 days-fattening. As a result of the economic analysis, the daily cost per animal, and output/input ratio for Tuj lambs in the extensive, semi-intensive, and intensive fattening systems were respectively determined to be $€ 0.94 \mathrm{TL}-1.05$, $€ 1.69 \mathrm{TL}-1.20$, and $€ 1.99 \mathrm{TL}-1.12$ and the same values were respectively determined to be $€$ 0.95 TL-1.04, $€ 1.70 \mathrm{TL}-1.11$, and $€ 2.00 \mathrm{TL}-1.09$ for Hemşin lambs. All the fattening systems are statistically different from each other in the fattening of Tuj and Hemşin lambs in terms of total costs $(\mathrm{P}<0.001)$. On the other hand, a statistically significant difference was determined between the extensive fattening system and other fattening systems in terms of net profit and output/input ratios $(\mathrm{P}<0.001)$. In conclusion, as the total costs, $1 \mathrm{~kg}$ carcass, $1 \mathrm{~kg}$ live weight gain, and $1 \mathrm{~kg}$ live weight costs are lower; on the other hand, as net profit and input/output ratios in the semi-intensive fattening system are higher compared to the intensive fattening system, for Tuj and Hemşin lambs the semi-intensive fattening system is recommended.

Keywords: Cost/benefit, Hemşin, lamb fattening, profitability, Tuj.

\section{Kontrollü koşullarda Tuj ve Hemşin kuzularıyla yapılan farklı besi sistemlerinin fayda/maliyet analizi}

Özet: Bu araştırma ile Türkiye' de ilk defa kontrollü koşullar altında farklı besi sistemlerinde kuzu beslemenin ekonomik analizi yapılarak, en karlı olan besi sisteminin belirlenmesi amaçlanmıştır. Araştırma materyalini Tuj ve Hemşin genotiplerinden 2.5-3 aylık yaşta sütten kesilmiş, 39'ar baş erkek kuzu oluşturmuştur. Çalışmada kuzular sistematik örnekleme metoduyla çapraz olarak her grupta 13 baş Tuj ve 13 baş Hemşin olacak şekilde ekstansif, yarı entansif ve entansif olmak üzere 3 farklı besi grubuna ayrılmış ve 90 günlük besiye tabi tutulmuştur. Ekonomik analiz sonucunda Tuj kuzularında ekstansif, yarı-entasif ve entansif besi sistemlerine göre hayvan başına günlük maliyet ve output/input oranı sırasıyla も 0.94 TL-1.05, も 1.69 TL-1.20 ve も 1.99 TL-1.12 iken, aynı değerler Hemşin kuzularında ise sırasıly も 0.95 TL-1.04, も 1.70 TL-1.11 ve 2.00 TL-1.09 olarak tespit edilmiştir. Tuj ve Hemşin kuzularının besisinde toplam masraflar yönünden bütün besi sistemleri birbirinden istatistik olarak farklıdır $(\mathrm{P}<0.001)$. Diğer taraftan net kar ile output/input oranı açısından ise ekstansif besi sistemi ve diğer besi sistemleri arasında istatistik olarak anlamlı bir fark tespit edilmiştir $(\mathrm{P}<0.001)$. Sonuç olarak; entansif besi sistemine göre yarı-entasif besi sisteminde toplam masrafların, 1 kg karkas, 1 kg canlı ağırlık artışı ve 1 kg canlı ağırlık maliyetinin daha az oluşu ve diğer taraftan net karın, output/input oranının daha fazla olması nedeniyle Tuj ve Hemşin kuzuları için yarı-entansif besi sistemi önerilmektedir.

Anahtar sözcükler: Fayda/maliyet, Hemşin, karlılık, kuzu besisi, Tuj.

\section{Introduction}

Sheep breeding is a livestock subsector performed in many parts of the world, and it is important in terms of its contribution to the economy and human nutrition. This importance results from the capability of sheep to properly utilize low-quality pastures and meadows, field crops, and vegetation not consumed by the cattle and to transform them into animal products (1).
According to the 2012 data of the Food and Agriculture Organization, average sheep carcass weight is $16.0 \mathrm{~kg}$ in Turkey, and it is lower than many countries such as United States, Australia, and New Zealand, which are in the forefront of sheep breeding (10). The reasons for the low carcasses in Turkey can be pointed out as low yield indigenous races, high rate of early lamb slaughters, 
and transfer of animals to slaughter after pasture fattening without being subject to intensive fattening $(1,9)$.

According to the 2015 data of the Turkish Statistical Institute, $93.00 \%$ of Turkey's sheep stock consists of indigenous sheep races (23). The reasons for breeders to prefer indigenous races are their fine adaptability to regional conditions, their resistance to disease, and well utilization of low-quality pastures. Among indigenous races, the Tuj is generally bred in Kars; and the Hemşin is bred especially in the province of Artvin and its surroundings $(2,18,19)$.

In a study on determining fattening performance of Tuj lambs grazed on pastures, first weight of male and female lambs on the pasture are identified respectively $8.78 \mathrm{~kg}$ and $8.80 \mathrm{~kg}$ and as a result of 140 days-pasture fattening, post fattening weights are identified respectively $34.24 \mathrm{~kg}$ and $31.90 \mathrm{~kg}$. In the same study, live weight gain (LWG) for male and female lambs are notified respectively as $181.6 \mathrm{~g}$ and $164.9 \mathrm{~g}(12)$.

In a study aiming to ascertain slaughtering and carcass features of different fattening methods, lambs are fed on pasture, pasture $+200 \mathrm{~g}$, pasture $+400 \mathrm{~g}$ feed at the end of 90 days-fattening, slaughtering weight of respective groups are identified $44.10 \mathrm{~kg}, 44.86 \mathrm{~kg}$ and $46.00 \mathrm{~kg}$, hot carcass weights are $20.66 \mathrm{~kg}, 21.36 \mathrm{~kg}$ and $22.15 \mathrm{~kg}$ and the outputs of hot carcass are $46.85 \%$, $47.56 \%$ and $47.64 \%$ (19).

In a study on Hemşin lambs, first weight on the pasture is determined as $28.09 \mathrm{~kg}$, post pasture weight as $39.27 \mathrm{~kg}$, daily live weight gain as $162.48 \mathrm{~g} \mathrm{(21).} \mathrm{Sari} \mathrm{et}$ al. (20) determined in order of extensive, semi-extensive and intensive fattening slaughter weight $32.71 \mathrm{~kg}, 41.38$ $\mathrm{kg}$ and $41.49 \mathrm{~kg}$, hot carcass weight $14.24 \mathrm{~kg}, 19.21 \mathrm{~kg}$ and $20.44 \mathrm{~kg}$, and cold carcass weight $13.73 \mathrm{~kg}, 18.79 \mathrm{~kg}$ and $19.94 \mathrm{~kg}$ in the article where for the same study datum they prove slaughter and carcass characteristics of Hemşin lambs.

Aydin et al. (6) defined the optimum fattening period of Hemşin lambs for the same study datum; according to this, while for Tuj lambs, fattening period when the marginal income is highest is in order of extensive, semiextensive and intensive systems $70^{\text {th }}, 84^{\text {th }}$ and $42^{\text {nd }}$ days, for Hemşin lambs it is in the same order $70^{\text {th }}, 28^{\text {th }}$ and $56^{\text {th }}$ days. In accordance with these, for Hemşin and Tuj lambs, optimum fattening period of intensive fattening system is shorter.

Lamb fattening is conducted in various forms depending on factors such as the enterprise structure, genetic level of the bred race, pasture status, methods of care and feeding, market conditions, and livestock policies of the country. The degree of profitability of lamb fattening depends on the production of high quantity of good-quality lamb meat in a short period of time at a low cost $(16,19)$. As the case is in all economic enterprises, the fundamental objective in lamb fattening enterprises is also to achieve maximum profitability. The factors directly affecting profitability in fattening enterprises are the increase in the live weight ( $\mathrm{LW}$ ) of fattened animals, feed consumption, feed conversion ratio (FCR), prices of input and output and the relations between them (5).

With this study, it is aimed to determine the most profitable fattening system through an economic analysis of different fattening systems under controlled conditions in lamb fattening performed for the first time in Turkey.

\section{Materials and Methods}

The materials of this study consist of certain parts of datum of TUBITAK project of which number is $111 \mathrm{O} 456$ for Hemşin genotype and Kafkas University Scientific Research Projects (SRP), the project of which number is VF-56 for Tuj genotype. Certain parts of variety of both project data have been utilized for cost/benefit analysis of diverse fattening systems. Certain parts of material section of the study have been delivered particularly in Sari et al (20) and Aydin et al. (6) articles which the results of the same project take place in.

This study was conducted in 2012 and the material of the study consists of 39 Tuj and 39 Hemşin male lambs that have been weaned at 2.5-3 months of age. 39 Tuj and 39 Hemşin male lambs included in the scope of the study were separated into three fattening groups of extensive, semi-intensive, and intensive through the systematic random sampling method a way to include 26 lambs in each group (13 Tuj and 13 Hemşin lambs) and were subject to fattening for a period of 90 days.

The lambs in extensive and semi-extensive fattening were grazed for 8 hours a day in the pasture. In semiintensive fattening in addition to the pasture and intensive fattening, the lambs were given concentrated feed prepared as ad libitum. In addition to the concentrated feed, the lambs in intensive fattening were given on average $270 \mathrm{~g} / \mathrm{lamb} / \mathrm{day}$. The amount of feed given to animals was recorded daily.

Under the scope of the study, a total of 48 animals were slaughtered including 8 Tuj and 8 Hemşin lambs in each fattening system. The hot and cold carcass weights were determined after the slaughter.

According to the extensive, semi-extensive and intensive fattening systems belonging to Tuj lambs which form basis for the economic analysis of the study, initial live weights (Mean \pm SEM) are respectively $20.62 \pm 0.76$ $\mathrm{kg}, 20.55 \pm 0.74 \mathrm{~kg}$ and $20.66 \pm 0.73 \mathrm{~kg}$; final live weights are $31.19 \pm 0.88 \mathrm{~kg}, 41.22 \pm 1.55 \mathrm{~kg}$ and $40.56 \pm 1.49 \mathrm{~kg}$; slaughter weights are $31.13 \pm 0.68 \mathrm{~kg}, 41.55 \pm 1.14 \mathrm{~kg}$ and $39.85 \pm 1.21 \mathrm{~kg}$; cold carcass weights are $12.93 \pm 0.33 \mathrm{~kg}$, $19.03 \pm 0.59 \mathrm{~kg}$ and $19.35 \pm 0.86 \mathrm{~kg}$. According to the extensive, semi-extensive and intensive fattening systems belonging to Hemşin lambs, initial live weights (Mean \pm 
SEM) are respectively $22.42 \pm 0.56 \mathrm{~kg}, 22.99 \pm 0.54 \mathrm{~kg}$ and $22.92 \pm 0.55 \mathrm{~kg}$; final live weights are $33.32 \pm 0.64 \mathrm{~kg}$, $41.16 \pm 1.36 \mathrm{~kg}$ and $42.09 \pm 1.09 \mathrm{~kg}$; slaughter weights are $32.71 \pm 0.54 \mathrm{~kg}, 41.38 \pm 1.38 \mathrm{~kg}$ and $41.49 \pm 0.79 \mathrm{~kg}$; cold carcass weights are $13.73 \pm 0.35 \mathrm{~kg}, 18.79 \pm 0.81 \mathrm{~kg}$ and $19.94 \pm 0.47 \mathrm{~kg}(6,20)$.

When the economic analysis of the study was being performed, the value averages obtained for the 8 lambs slaughtered in each fattening system for each genotype were accepted to be valid for 13 animals. The cost elements of fattening material, concentrate feed, roughage, labor, health-medicine, electricity-water, pasture, and slaughtering the economic analysis were determined at 2012 current prices by conducting market research in the province of Kars, where the study was conducted (13). General administrative costs were accepted as $3 \%$ of fattening material, concentrate feed, roughage, labor, health-medicine, and electricity-water, and pasture costs $(3,17)$. After the sheepfold amortization expense was calculated using the straight-line method, the amount of amortization corresponding to 90 days was calculated.

The items of carcass, edible inner organs (heart, liver, spleen, and lung), pelt, head-foot, and intestinebowel income constituting the income were calculated by considering 2012 current prices in the province of Kars (13). Cold carcass weight was taken into consideration in the calculation of carcass income. Sheepfold maintenancerepair and litter floor expenses, and the secondary income of manure were not taken into consideration in the study as they were very low and did not reflect a significant difference between fattening groups.

In cost/benefit analysis of Tuj and Hemşin lambs according to different fattening systems, net profit was determined by subtracting the total costs from the total income. In the study, $1 \mathrm{~kg}$ carcass, LW, LWG cost, partial efficiency of feed, and output/input ratio were calculated according to literature information $(3,7)$. In the determination of partial efficiency of feed under the scope of the study, the dry matter amounts of concentrate and roughage were respectively determined as $88.80 \%$ and $90.69 \%$.

In the study, the determination of the descriptive statistics of the data and the significance tests of differences among groups have been conducted utilizing the T-test in double comparisons and utilizing the one-way analysis of variance in triple comparisons. The SPSS 20.0 statistics package program was used for the analyses (22).

\section{Results}

Tuj and Hemşin lambs according to fattening systems the economic analysis chart, partial efficiency of feed and output/input ratio is provided in Table 1 .
As it can be observed in the economic analysis chart, it was determined that the extensive fattening system was the system with the lowest cost in Tuj and Hemşin lambs. The reason for the total cost difference between the fattening systems within the two genotypes is due to the changes in feed costs. As a matter of fact, a statistically significant difference was determined between all of the fattening systems in Tuj and Hemşin lambs in terms of total cost $(\mathrm{P}<0.001)$.

When the income in lamb fattening is examined, it can be observed that the greatest portion is obtained from carcass. Within both genotypes, the difference of carcass, total income, and net profit values determined for the extensive fattening system from the values obtained from other fattening systems was determined to be statistically significant $(\mathrm{P}<0.001)$. No statistically significant difference was determined between semi-intensive and intensive fattening systems in terms of income data ( $\mathrm{P}>0.05)$. In other words, when net profit is examined, it was determined that the extensive fattening system was the system with the least profitability.

On the other hand, the semi-intensive fattening system is the system with the lowest $1 \mathrm{~kg}$ carcass and LW cost and the most net profit and output/input ratio in both Tuj and Hemşin lambs. In the study, partial efficiency of feed was determined only for the intensive fattening system, and this value was calculated as $0.171 \mathrm{~kg}$ carcass in Tuj lambs and $0.176 \mathrm{~kg}$ carcass in Hemşin lambs.

\section{Discussion and Conclusion}

When 2015 data of TURKSTAT is examined, it can be observed that $8.70 \%$ of the total red meat production in Turkey is provided from sheep-lamb meat (23). It is considered that the practice of lamb fattening after the ablactating of sucking lambs will cause an important increase in the total red meat production in Turkey. The importance of the lamb fattening system to be implemented becomes apparent at this point.

In the study, it was determined that the intensive fattening system had the highest enterprise costs after the fattening of Tuj and Hemşin lambs, and the semi-intensive and extensive systems followed the intensive fattening system, respectively. On the other hand, it was determined that the highest income in total enterprise income was in the same order as intensive, semi-intensive, and extensive fattening systems. However, while there was no significant difference between the semi-intensive and intensive fattening systems when the total income was compared according to fattening systems in both genotypes $(\mathrm{P}>0.05)$, it was determined that the difference between these two fattening systems and the extensive fattening system was important $(\mathrm{P}<0.001)$. Furthermore, when the statistical significance test of the net profit between fattening systems was performed, it was observed 


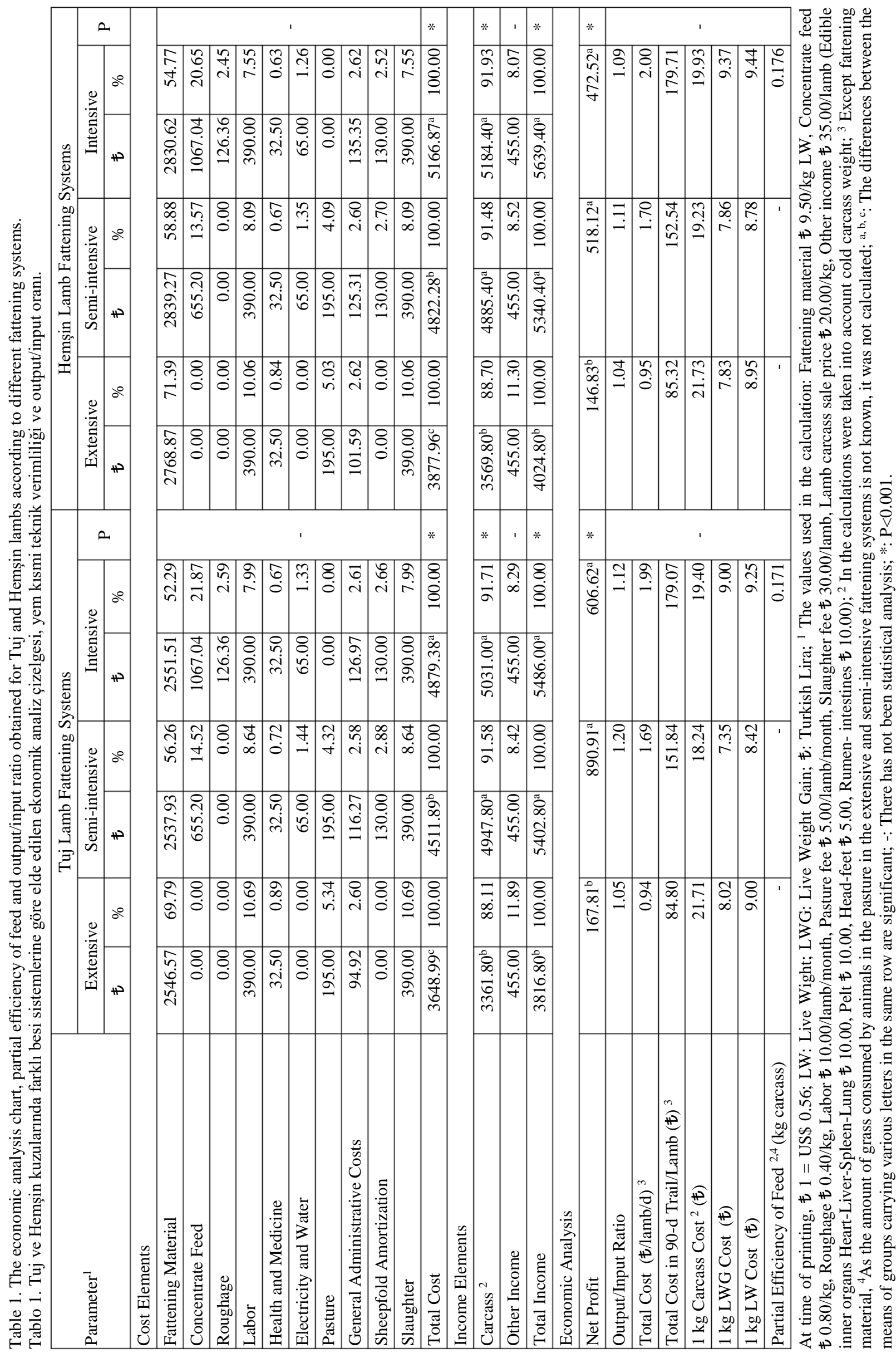


that the difference between the extensive fattening system and the other fattening systems was significant $(\mathrm{P}<0.001)$. On the other hand, while the highest net profit and output/input ratio, the lowest $1 \mathrm{~kg}$ carcass and $\mathrm{LW}$ cost were obtained in the semi-intensive fattening system in the fattening of both Tuj and Hemşin lambs, the lowest net profit and output/input ratio and highest $1 \mathrm{~kg}$ carcass cost were determined in the extensive fattening system.

In the study conducted by Cevger (7) at lamb fattening enterprises between the years of 1993-1995 in the province of Karaman, the output/input ratio was reported to be 1.37 in small sized enterprises, 1.51 in medium sized enterprises, and 1.59 in large sized enterprises. These values are higher than the value of the highest calculated semi-intensive fattening system input/output ratio among the study findings. It is considered that the difference in output/input ratios in the studies is due to the years the studies were conducted. As a matter of fact, in the study conducted by Aydin et al. (4), it was reported that in the last 25 years, there have been important changes in real terms in fattening material and feed prices in Turkey.

In the study conducted by Rihawi et al. (15) in Syria, the total cost excluding fattening materials throughout the 49-day fattening process for Awassi lambs varied according to test groups, and was calculated between US\$ 8.97-11.27 (At time of printing, $₹ 1=$ US\$ 0.56). On the other hand, in the studies of Hartwell et al. (11), the total cost excluding fattening material in Awassi lambs subject to fattening for a period of 90 days with the extensive fattening system and with three different rations was reported to be between US\$22.2-25.0, and the cost for 1 $\mathrm{kg}$ LWG was reported to be US\$ 0.89-0.98. These values are at a relatively lower level than the value calculated for Tuj and Hemşin lambs in the study. It is considered that this is due to expenses varying according to countries such as feed and labor.

Even though the extensive fattening system has the lowest production cost compared to other fattening systems, it was striking that it had the lowest net profit. The basic reason of this is the lower total LWG observed in the extensive fattening system and the cold carcass weight in parallel with this. The main reason for this is the fact that carcasses constitute the greatest portion of income items according to study findings. Within the framework of these findings, in terms of fattening methods, it is possible to say that maximum benefit could not be obtained as carcass from fattening material in the extensive system. In a manner supporting the findings of this study, Kaygisiz et al. (14) reported that enterprise income was largely ensured from LWG in lamb fattening.

It is considered that the preference of the extensive lamb fattening system by lamb fattening enterprises can only be possible with the higher kilogram price of the obtained carcass. In the free market economy, selling of the carcass obtained as a result of extensive lamb fattening at a higher price due to aroma, rate of fat, appearance and similar factors can only occur with the establishment of the quality-price relation. However, there is no qualityprice relation for red meat in Turkey (8).

The difference between the average cold carcass weights of Tuj and Hemşin lambs according to fattening systems (such as Tuj extensive-Hemşin extensive) and carcass income parallel to this were not significant in all three match-ups $(\mathrm{P}>0.05)$. Furthermore, the partial efficiency of feed in the intensive fattening system was calculated at a higher value for Hemşin lambs. Despite these two important factors, the net profit obtained from Tuj lambs in all fattening systems was determined to be at a higher value than the net profit obtained from Hemşin lambs. It is considered that the most important factor influencing this is the higher average weight of tail fat obtained from Tuj lambs. As a matter of fact, the cold tail fat weight included in the cold carcass weight in the study was determined to be $2.72 \mathrm{~kg} / \mathrm{lamb}$ on average in Tuj lambs and $1.92 \mathrm{~kg} / \mathrm{lamb}$ on average in Hemşin lambs. While the difference in tail fat amounts between Tuj and Hemşin lambs was not significant in the extensive fattening system $(\mathrm{P}>0.05)$, it was determined to be important among other fattening systems $(\mathrm{P}<0.05)$.

In conclusion, there is an important difference between the extensive fattening system and other fattening systems for Tuj and Hemşin lambs in terms of net profit. Even though the difference between total costs in the semi-intensive fattening system and intensive fattening system is significant, it was determined that the difference between total income and net profit was not significant. Within the framework of these findings, as the total costs, $1 \mathrm{~kg}$ carcass, LWG, and LW costs are lower; on the other hand, as net profit and input/output ratios in the semiintensive fattening system are higher compared to the intensive fattening system, the semi-intensive fattening system is recommended as the most rational lamb fattening system.

\section{Acknowledgements}

The materials of this study consist of certain parts of datum of TUBITAK project of which number is $111 \mathrm{O} 456$ and Kafkas University Scientific Research Projects (SRP), the project of which number is VF-56. The authors gratefully acknowledge to TUBITTAK and Kafkas University SRP due to the financial contribution in every phase of the study.

\section{References}

1. Akcapinar H (2000): Sheep Breeding (in Turkish), $2^{\text {nd }}$ Edition, Ismat Publishing, Ankara. 
2. Aksu Elmali D, Demir P, Kaya İ (2010): Cost-benefit analyses of feeding with different concentrate feeds in Tuj (Tushin) lambs. Kafkas Univ Vet Fak Derg, 16, 771-775.

3. Aydin E (2011): Economic analysis of intensive fattening enterprises in the provinces of Kars and Erzurum. Ankara University, Institute of Health Sciences, Doctoral Thesis, Ankara.

4. Aydin E, Aral Y, Can MF, et al. (2011): Analysis of the red meat price changes over the last 25 years and effects of import decisions in Turkey. Vet Hek Der Derg, 82, 3-13.

5. Aydin E, Sakarya E (2012): Economic analysis of intensive cattle fattening enterprises in the provinces of Kars and Erzurum. Kafkas Univ Vet Fak Derg, 18, $997-$ 1005.

6. Aydin E, Sari M, Onk K, et al. (2014): Determination of the optimum fattening period of Tuj and Hemşin lambs according to different fattening systems. Kafkas Univ Vet Fak Derg, 20, 835-840.

7. Cevger Y (1997): Analysis of profitability and productivity of lamb fattening enterprises in Karaman province. Vet $\mathrm{J}$ Ankara Univ, 44, 277-290.

8. Cevger Y, Aral Y, Demir P, et al. (2008): The situation of animal products consumption and consumer preferences among intern students at the Ankara University Faculty of Veterinary Medicine. Vet J Ankara Univ, 55, 189-194.

9. Ekiz B, Yilmaz A, Ozcan M, et al. (2009): Carcass measurements and meat quality of Turkish Merino, Ramlic, Kivircik, Chios and Imroz lambs raised under an intensive production system. Meat Sci, 82, 64-70.

10. FAOSAT (2016): Food and Agriculture Organization, Animal Production Statistics, http://faostat.fao.org/site/569/ default.aspx\#ancor, Access Date: 04.04.2016

11. Hartwell BW, Iniguez L, Knaus WF, et al. (2010): A wassi lamb growth responses and carcass traits, and economic benefits associated with reduced-cost diets made from locally available feed resources, Small Ruminant Res, 93, 48-52.

12. Ișık S, Kaya İ (2011): The effect of vegetation period on the qualilty of pasture and performance of grazing Tujhin sheep and lambs. Kafkas Univ Vet Fak Derg, 17, 7-11.

13. Kars Trade Exchange (2012): Live animals and animal products prices. http://www.karstb.org.tr, Access Date: 15.12.2012
14. Kaygisiz F, Elmaz O, Keser O (2006): The impacts of weight and price margins on the incomes in Kivircik lamb fattening. J Fac Vet Med Istanbul Univ, 32, 53-58.

15. Rihawi S, Iniguez L, Knaus WF, et al. (2010): Fattening performance of lambs of different Awassi genotypes, fed under cost-reducing diets and contrasting housing conditions. Small Ruminant Res, 94, 38-44.

16. Sakarya E (1998): The importance and sheep husbandry in Turkey (in Turkish). Journal of Ekin, 2, 33-37.

17. Sakarya E, Gunlu A (1996): A study on determination of optimal fattening period of Limuzin X Jersey cross-breeds and Holstein bulls, Vet J Ankara Univ, 43, 113-120.

18. Sari M, Aksoy AR, Tilki M, et al. (2012): Effect of different fattening methods on slaughter and carcass characteristics of Tuj male lambs. Arch Tierzucht, 55, 480484.

19. Sari M, Onk K, Aydin E, et al. (2014): Effects of different fattening systems on fattening performance and body measurements of Hemsin male lambs. Kafkas Univ Vet Fak Derg, 20, 209-215.

20. Sari M, Onk K, Aksoy AR, et al. (2015): Effects of different fattening systems on slaughter and carcass traits of male Hemsin lambs. Vet J Ankara Univ, 62, 147-152.

21. Sezgin E, Kopuzlu S, Yüksel S, et al. (2012): Determination of growth traits and heritabilities of growth characteristics of Hemşin sheep reared in Artvin. Kafkas Univ Vet Fak Derg, 18, 899-905.

22. SPSS (2012): For windows, 2012: Release 20.0. Standard version. Copyright SPSS Inc.

23. TURKSTAT (2016): Turkish Statistical Institute, Livestock Statistics. https://biruni.tuik.gov.tr/hayvancilik app/hayvancilik.zul, Access Date: 04.04.2016.

Geliş tarihi: 03.02.2014 / Kabul tarihi: 15.06.2016
Address for correspondence:
Assist. Prof. Dr. Erol AYDIN
Kafkas University, Veterinary Medicine Faculty
Department of Livestock Economics and Management
TR - 36300, Kars, Turkey.
Tel: +90 $4742426807 / 5099$
e-mail:dr-erolaydin@hotmail.com 